\title{
THE INFLUENCE OF ALIGNING INFORMATION TECHNOLOGY (IT) STRATEGY, PERFORMANCE CONTRACT AND IT ORGANIZATIONAL STRUCTURE ON INSTITUTIONAL PERFORMANCE. CASE OF KENYAN PUBLIC UNIVERSITIES.
}

\author{
Waweru Zachary K and Wausi Agnes N \\ College of Biological and Physical Sciences, School of Computing, \\ University of Nairobi, Kenya.
}

\begin{abstract}
Strategic alignment of Information Technology (IT) with Corporate Strategy remains a key concern for enterprises and scholars over decades. Strategic IT alignment is widening its adoption across globe due to its empirically proven capability of improving organizational performance. Most of the studies on strategic alignment have however focused on developing countries and thus creating a significant gap in the alignment research. This paper presents how strategic IT alignment can be used in a developing country setting to improve both institutional performance and innovation. The hindrances and theoretical implications of strategic alignment in a developing country setting are also discussed and future research direction explored.
\end{abstract}

The findings in this study have shown that when IT strategy is aligned with Performance contract, institutional performance is improved; when IT strategy is aligned with IT organizational structure, institutional performance is enhanced; and, there is a positive effect on institutional performance when IT strategy is aligned with Performance contract and IT organizational structure.

\section{KEYWORDS}

Strategic IT alignment, Institutional performance

\section{INTRODUCTION}

The concept of strategic IT alignment continues to be a valuable concern for corporate directors that look forward to achieve alignment of their business and technology strategies [4].Strategic IT alignment has been seen as an enabler for organizations that look forward to realizing value from their IT investments [13]. In addition, it allows an organisation to dedicate critical IT resources to vital areas to address business challenges and improve business value [8].Although past research has investigated the underlying factors that lead to strategic alignment and improvement of business performance $[8,29,28,10]$, there is little emphasis of strategic alignment in developing countries and academic institutions. Additionally, most of the studies have measured alignment based on business' strategic plans and thus neglecting other corporate strategies employed in business. This paper addresses these gaps by assessing strategic IT alignment in public 
universities of a developing country using performance contracts as a corporate strategy. The paper is divided into four major sections. The first section gives a theoretical background of strategic IT alignment based on which the researcher formulates research hypotheses. Section two illustrates the developed research model and hypotheses. In the third section we present the research methods for data collection and analysis and discuss the research findings. Finally we give contributions and limitations of this study, and suggest future research directions.

\section{THEORETICAL FOUNDATION OF STRATEGIC ALIGNMENT}

The main goal behind strategic alignment also referred to as "fit" is to take an organisation as a system with many functional parts and align them to operate towards the same end with an objective of realizing expected outputs. It also aims at making sure that business strategy, IT strategy, organizational infrastructure and processes, and IT infrastructure and processes within an organization are all in harmony [7].

The concept of Business/IT alignment or "fit" is seen to have been conceptualized by Henderson \&Venkatraman [12] who later published an article "Strategic Alignment: Leveraging Information Technology for transforming organizations". This concept has remained very valuable to corporate directors looking to achieve alignment of their business and technology strategies [4]. The definition of strategic alignment differs among different researchers. Broadbent \& Weill [3] for example, defines strategic alignment as the extent to which business strategies are enabled, supported and stimulated by information strategies. Strategic alignment is also defined as the activities that management performs to achieve cohesive goals across the IT and functional (e.g., finance, marketing, manufacturing) organizations [20]. Others view strategic alignment as an ITBusiness relationship that is how IT relates to the business and the reciprocal of it that shows how the business should be in harmony with IT. Some of the operational terms that have been synonymously used in literature to refer to the concept of alignment include fit, integration, linkage and fusion among others. In all the cases however, the terms refer to the harmonization of both IT with business strategies.

Strategic alignment or "fit" is built on the foundation that competitive situation, strategy, culture and leadership can be described as a combination of four "logics" (production, administration, development and integration) which are combined in various ways to produce a unique competitive situation, strategy, and culture or leadership style [9].

\subsection{Strategic Alignment Model (SAM)}

The Strategic alignment model was developed in 1989 by Henderson \&Venkatraman to clearly demonstrate the various constructs necessary in achieving strategic alignment. The model comprised of two fundamental dimensions i) strategic integration and ii) functional integration. The model further distinguishes between the business domain (business strategy and business processes) and the technology domain (information strategy and IT processes, including systems development and maintenance) in an organization [12]. The model is shown below. 
International Journal of Managing Public Sector Information and Communication Technologies (IJMPICT)

Vol. 8, No. 2, June 2017

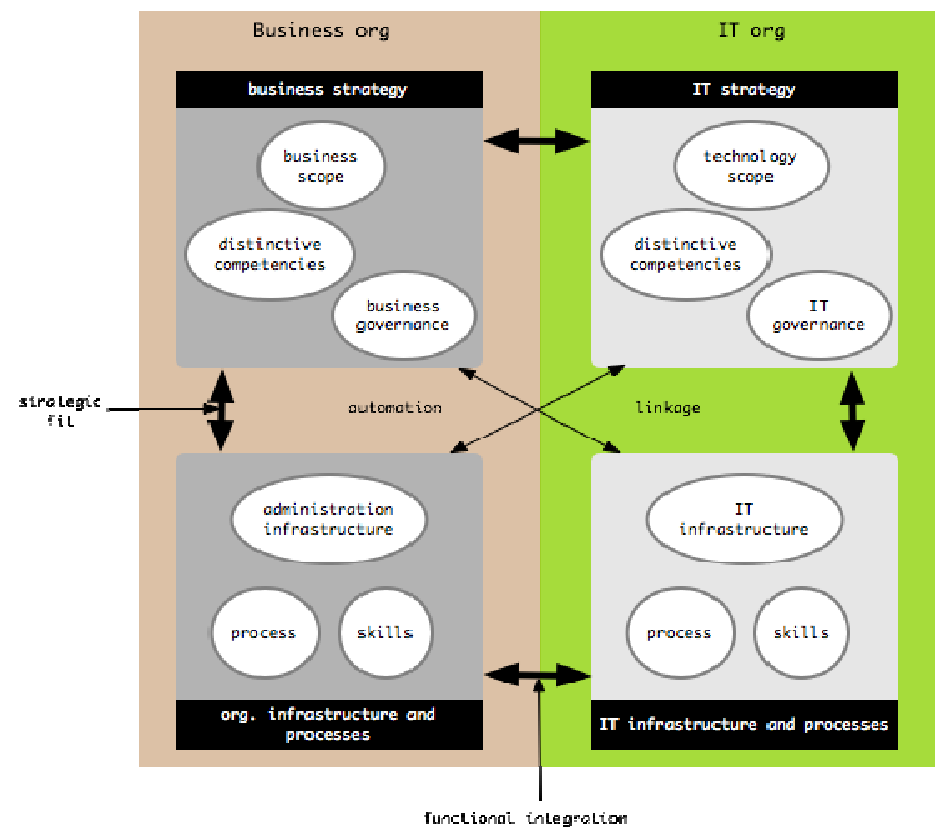

Fig. 1: Strategic Alignment Model

The term "Strategic fit" as used in the model describes the interrelationships between the external domain and the internal domains. Functional integration on the other hand describes the integration between the business and technology domains. Strategic alignment at an organizational level can only occur when three of the four domains are in alignment and that neither strategic fit nor functional integration alone is enough to effectively align an organisation [13]. This means that if change happens in one domain, it will affect at least two other domains.

Two major enhancements that have arisen from the original Henderson \&Venkatraman model include the Luftman's [20] and the Maes' [21] unified frameworks. Luftman's enhancement, though it did not modify the original model, defines the classical model in a more practical way [2] with the results of their research confirming that:

i) Communication and support between business and technology management are the major enablers and/or inhibitors to alignment; and ii) it is very important for an organisation to include IT management in the strategic planning process.

Maes' enhancement involves a unified framework that includes additional functional and strategic layers to reflect the current needs for information and communication. The framework is shown in Fig. 2 below. 
International Journal of Managing Public Sector Information and Communication Technologies (IJMPICT)

Vol. 8, No. 2, June 2017

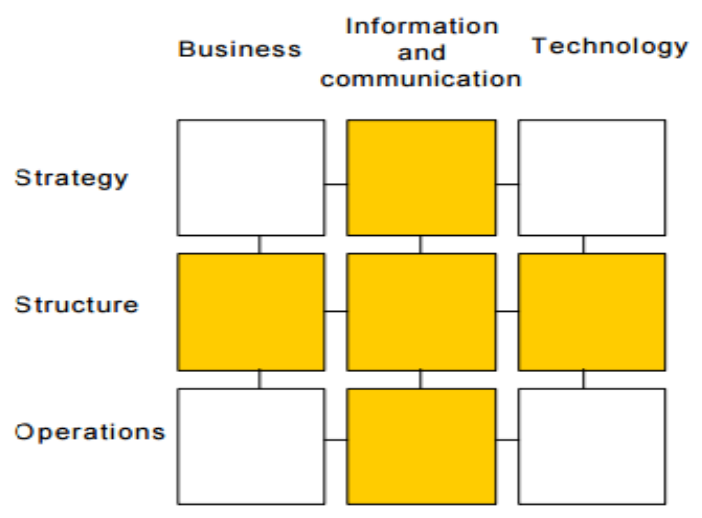

Fig. 2: A generic framework for the business - IT relationship

Nevertheless, the original Henderson \&Venkatraman model, extended by both elaborations of Luftman, is still the unchallenged model for business - IT alignment which continues to be used by many scholars as a framework for aligning their business with IT [21].

It is on the basis of this findings that this paper employed use of the strategic IS alignment model to assess alignment of IT, performance contract and institutional performance in Kenyan public universities.

\subsection{Research Gaps in the strategic alignment Literature}

Although literature on strategic alignment has shown a positive effect on organisational performance, a few questions remain un answered.

i) Is the same effect of alignment attainable within an academic institution setup?

ii) Can performance contract, as a corporate strategy, achieve the performance results?

iii) Can the same effects of strategic alignment be realised in a developing country setting?

Without consideration of these factors, strategic alignment Literature would be biased and incomplete.In the next section, this paper attempts to bridge the research gap through formulating of hypothesis based on the existing literature and development of an adapted strategic alignment model.

\subsection{Hypothesis Formulation}

\subsubsection{IT -Performance Contract (Corporate Strategy) alignment}

Information Technology (IT) is seen as an enabler and driver of business that provides competitive advantage which brings value to the business.

Some of the value realized from IT investments is cost reduction; profit growth, improved speed of operation and consistency of data generation, accessibility and exchange of information [18]. Performance contract is defined as a written agreement between government and a state agency (local authority, State Corporation or central government ministry) delivering services to the public, wherein quantifiable targets are explicitly specified for a period of one financial year and 
International Journal of Managing Public Sector Information and Communication Technologies (IJMPICT)

Vol. 8, No. 2, June 2017

performance measured against agreed targets [17]. Performance contract is therefore a corporate strategy that draws quantifiable targets from the strategic plan of the organisation and the central Government's strategic goals.

Performance contracting was first introduced in Kenya in 2004 through a result based management strategy that aimed at improving performance, service delivery and governance strategy in the Public Service. The Government of Kenya first introduced the strategy to ministries and state agencies and eventually to county governments created through a new constitution enacted in 2010. The process of performance contracting involves the parties involved setting targets based on their strategic plan and using guidelines provided for by the GoK at the beginning of each financial year $\left(\mathrm{July} 1^{\text {st }}\right)$.

IT alignment with the performance contract can therefore be seen as the harmonization of the IT strategy, of the public institution under contract, with the agreed set of performance targets in the performance contract.

This definition agrees with most studies in the area of strategic alignment that have focused on measuring the resultant effect of this alignment which mainly focuses on performance. Several studies exist that show the existent of a positive effect of strategic alignment on organizational performance as shown in Table 1.

Table 1: Selected studies that have examined the relationship between strategic IT alignment and organizational performance

\begin{tabular}{ll}
\hline Author & Findings \\
\hline Sohal and Lionel (1993) & $\begin{array}{l}\text { If the role of IT is maximized within an } \\
\text { organizational strategy, IT usage will enhance } \\
\text { organizational performance }\end{array}$ \\
\hline $\begin{array}{l}\text { Kearns \&Lederer, } \\
\mathbf{2 0 0 3}\end{array}$ & $\begin{array}{l}\text { Positive effect of alignment on business competitive } \\
\text { advantage }\end{array}$ \\
\hline Chan et al, 2006 & $\begin{array}{l}\text { Positive effect of alignment on firm performance } \\
\text { and US academic institutional } \\
\text { performance }\end{array}$ \\
\hline $\begin{array}{l}\text { Schniederjans\& } \\
\text { Cao (2009) }\end{array}$ & $\begin{array}{l}\text { Positive impact of strategic alignment on } \\
\text { performance }\end{array}$ \\
\hline Yayla and Hu (2012) & $\begin{array}{l}\text { Strategic alignment between IT and business has a } \\
\text { significant impact on performance across all choices } \\
\text { of strategic orientation - defender, prospector, or } \\
\text { analyzer. }\end{array}$ \\
\hline
\end{tabular}

Based on the literature reviewed, we would therefore expect that for those institutions that have aligned their IT strategy with corporate strategy, in this case the performance contract, should have high returns on IT investments and thus improved performance.

We therefore formulate our first hypothesis: H1:Alignment between IT strategy and Performance Contract has a positive statistical significant effect on institutional performance. 


\subsection{IT - IT Organizational Structure Alignment}

IT organizational structure or governance involves activities like IT planning, IS decisionmaking, IT coordination, and IT control within an organization that determines how the roles, and duties are assigned, controlled, and coordinated, and how information flows between the different levels of management.

IT structure can be classified into three categories [26] namely:

i) Centralized: This is where corporate IT management has IT decision-making authority concerning infrastructure, applications, and development.

ii) Decentralized: This involves division IT management and business-unit management having authority for infrastructure, applications, and development.

iii) Hybrid: this is a hybrid configuration of centralization and decentralization, where corporate IT has authority over infrastructure, and division IT and business-units have authority over applications and development.

Centralization provides greater efficiency and standardization, while decentralization improves business ownership and responsiveness [26]. Due to increased uncertainty and complexity, and multi-focused strategies, most organizations are adopting hybrid IT governance which require increased coordination [23].

IT organisational structure plays a major role in institutional performance .Immature IT structures are therefore a major reason why public organizations do not realize the benefits from IT investments [1].

Studies $[15,11]$ have shown that a performance of a firm depends on the degree of coherence between its structure, which is considered as a foundation of a firm's strategic technological choice, and its environment. Additionally, effective IT organizational structure, IT departments can better transform their resources according to business needs without destroying IT strategic goals and increase productivity by taking the advantage of information systems to conduct resource transformation more effectively with changing requirements [8].

Other studies [6] indicated a significant influence of organizational structure on firm profitability, and found that indeed the characteristics of IT organizational structure affect organizational performance.

This paper therefore perceives IT organizational structure as a key strategic alignment construct that influence firm's performance and this leads to our second and third hypotheses:

H2:Alignment between IT strategy and IT Organizational structure has a positive statistical significant effect on institutional performance; and

H3: Co- Alignment between IT strategy -Performance Contract and IT strategy-IT Organizational structure Alignment has a positive statistical significant effect on institutional performance. 


\subsection{Research Model}

The development of the research model was arrived at after reviewing the work of Henderson and Venkatraman [13], Luftman [20] ; Croteau et al. [10]; and Jouirou \& Kalika [16].

Findings from these studies suggest that organisation performance resulting from IT investment must take into considerations the alignment of the strategies and the organisational structure. This paper recognizes a performance contract as a corporate strategy since it draws its targets from the corporate strategic plan.

The metrics for performance were arrived at after reviewing the work of Hill [14], who asserts that for any organisation to attain operational effectiveness, five performance objectives are sought. These include cost, quality, flexibility, speed and reliability.

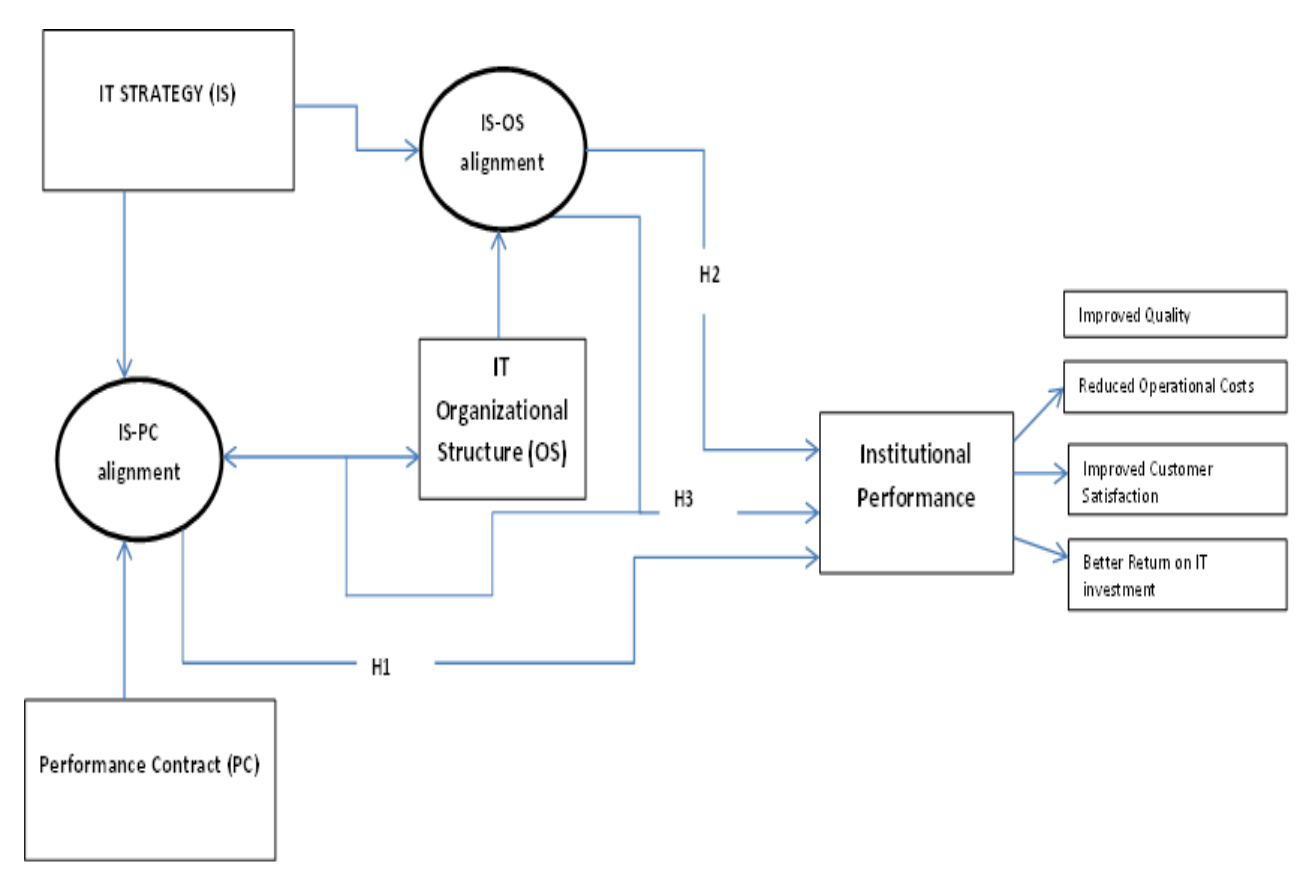

Figure 3: Strategic IS Alignment Model

In Figure 3, three independent variables were identified namely: IT Organisational structure, Performance contract and IT strategy. The dependent variable identified was institutional performance.

The model shows that, if a University wants to generate best performance levels, it should align its IT strategy with its corporate strategy and its IT organizational structure.

To test the relationship between various variables in the model, the researcher formulated the following hypothesis:

H1:Alignment between IT strategy and Performance Contract has a positive statistical significant effect on institutional performance. 
International Journal of Managing Public Sector Information and Communication Technologies (IJMPICT)

Vol. 8, No. 2, June 2017

H2:Alignment between IT strategy and IT Organizational structure has a positive statistical significant effect on institutional performance.

H3:Co- Alignment between IT strategy -Performance Contract and IT strategy-IT Organizational structure Alignment has a positive statistical significant effect on institutional performance.

\section{METHODOLOGY}

To test the model in the most accurate way possible, the study was conducted through a survey of all the public Universities in Kenya that had signed Performance contracts with the Government since the year 2010 .

We chose survey method for two primary reasons: i) It allowed for gathering of information for both independent and dependent variables using questionnaires and interviews [22]; and ii) it has been successfully applied in previous strategic alignment studies [24, 5,15] to assess the effect of strategic alignment on organisational performance.

After a thorough literature review, we developed a research instrument to collect data that would validate the research model and also test the hypotheses. Requests for participation in the survey was sent via email to the 20 participating public Universities. This included 5 requests to the interviewees and 20 questionnaire respodents.

A total of 25 invitations were sent. The respodents involved 20 Directors incharge of ICT in the public Universities and 5 Top managers in charge of performance contracting and strategy. At the end of the data collection process, we were able to conduct all the targeted 5 interviews and collect 17 usable questionnaires and this translated to $88 \%$ response rate.

\section{DATA ANALYSIS AND INTERPRETATION OF FINDINGS}

Data analysis involved both descriptive statistics and inferential statistics. Descriptive analysis was used to describe the data and mainly involved frequency distributions, calculation of mean and standard deviation. On the other hand inferential analysis involved correlation analysis to find the relationship between various variables.

\subsection{Response Rate}

The number of questionnaires that were dispatched was 20 as per Table 2 . The total number of questionnaires that were properly filled and returned was 17. This represented an overall successful response rate of $85.0 \%$. In addition, five interviews were conducted.

Table 2: Response rate for questionnaires

\begin{tabular}{lrr}
\hline Questionnaire Status & Frequency & \multicolumn{2}{c}{ Percentage Response } \\
\hline Returned & 17 & $85.0 \%$ \\
Not Returned & 3 & $15.0 \%$ \\
\hline Total & $\mathbf{2 0}$ & $\mathbf{1 0 0 . 0 \%}$ \\
\hline
\end{tabular}




\subsection{Alignment between IT Strategy and Performance Contract has a Positive Statistical Significant Effect on Institutional Performance}

The study findings showed that there exists an alignment between IT strategy and Performnce contracts in Kenyan public universities. An interviewee noted,

The IT director works closely with the Director of performance contracting to determine the priority targets, as provided for in the IT strategy of the institution, to be included as the performance contract targets. The Government of Kenya also releases mandatory automation guidelines to be adhered to during a financial year and the two must be in harmony.

Further, the study findings indicated a positive influence on instituional performance when IT strategy and Performance contract were aligned. The test results based on the quantitative datas showed that the regression model is significant with a $\mathrm{p}$ value of 0.001 as shown in table 3 . This shows that the model fitted the data well.

The fitted regression equation was, $\mathrm{y}=0.749 \mathrm{x}$ where:

$\mathrm{y}$ is institutional performance

$\mathrm{x}$ is alignment between IT strategy - performance contract

Table 3: Analysis of Variance (ANOVA) table for the Regression Model for Alignment between IT Strategy - Performance Contract and Institutional Performance

\begin{tabular}{lrrrrr}
\hline Model & \multicolumn{1}{l}{$\begin{array}{l}\text { Sum of } \\
\text { Squares }\end{array}$} & $\begin{array}{l}\text { Degrees of } \\
\text { freedom }\end{array}$ & $\begin{array}{l}\text { Mean } \\
\text { Square }\end{array}$ & F & Significance \\
\hline Regression & 1.715 & 1 & 1.715 & 19.135 & 0.001 \\
Residual & 1.344 & 15 & 0.090 & & \\
\hline Total & $\mathbf{3 . 0 5 9}$ & $\mathbf{1 6}$ & & & \\
\hline
\end{tabular}

This test agreed with the qualitative data which showed that strategic alignment of IT strategy and Performance contract has a great influence on automation of core processes and overall institutional performance in Kenyan Public Universities. The benefits according to the respondents included reduced operational costs, improved customer satisfaction and improved quality.

These results supported prior literature on strategic alignment[28] which asserted that the reasons why firms don't realize benefits from the huge IT investments is due to lack of alignment between IT strategy and business strategy.

It also supported our hypothesis:

H1:Alignment between IT strategy and Performance Contract has a positive statistical significant effect on institutional performance.

\subsection{Influence of alignment between the IT strategy and IT Organizational Structure on institutional Performance}

The findings of this study showed that IT strategy and IT organisational structure in Kenyan public universities are in alignment. In all the Universities under study, the highest IT executive 
reported directly to the chief executive (Vice chancellor) of that institution. He/she also sat in the top management meeting which was referred to as the senate and this helped in easy communication of strategy and implementation.

A respodent noted,

The IT director in my university reports directly to the Vice chancellor and sits in the senate. He even has the rare privilege of sitting in the Council or board meetings. This allows him to easily communicate the IT strategy and once it has the support of the management success is guaranteed."

Another respodent noted, Once an IT strategy has the support of the Top Management, implementation becomes very easy.

The study further indicated a positive influence on instituional performance when IT strategy and IT organisational structure were aligned. The test results based on the quantitative datas showed that the regression model is significant with a $\mathrm{p}$ value of 0.039 as shown in table 4 . This shows that the model fitted the data well.

The fitted regression equation was, $y=0.223 x$ where:

$y$ is institutional performance

$x$ is strategic IT - organizational structure alignment

Table 4: Analysis of Variance (ANOVA) table for the Regression Model for Strategic IT - Organizational Structure Alignment and Institutional Performance

\begin{tabular}{|c|c|c|c|c|c|}
\hline Model & $\begin{array}{l}\text { Sum of } \\
\text { Squares }\end{array}$ & $\begin{array}{l}\text { Degrees of } \\
\text { freedom }\end{array}$ & $\begin{array}{l}\text { Mean } \\
\text { Square }\end{array}$ & $\mathbf{F}$ & Significance \\
\hline Regression & 0.992 & 1 & 0.992 & 5.114 & 0.039 \\
\hline Residual & 2.907 & 15 & 0.194 & & \\
\hline Total & 3.899 & $\mathbf{1}$ & & & \\
\hline
\end{tabular}

The results of the regression test also agreed with the findings of the qualitative data that similarly showed a positive effect on instituional performance when IT strategy and IT Organisational structure was aligned. It further supported a study [8] that asserts that with effective IT organizational structure, IT departments can better transform their resources according to business needs without destroying IT strategic goals.

The results proved that our hypothesis H2:Alignment between IT strategy and IT Organizational structure has a positive statistical significant effect on institutional performance to be true.

\subsection{Co - Alignment between IT strategy - Performance Contract and IT strategy - IT Organizational Structure Alignment has a Positive Statistical Significant Effect on Institutional Performance}

A multiple regression model was formulated for the effect of co - alignment between IT strategy - performance contract and IT strategy - organizational structure alignment on institutional performance. The model was of the form:

$y=\beta_{1} x_{1}+\beta_{2} x_{2}$ where: 
International Journal of Managing Public Sector Information and Communication Technologies (IJMPICT)

Vol. 8, No. 2, June 2017

$y$ isinstitutional performance

$x_{1}$ isalignment between IT strategy - performance contract

$x_{2}$ is strategic IT - organizational structure alignment

$\beta_{1}$ and $\beta_{2}$ are the coefficients of $x_{1}$ and $x_{2}$ respectively.

The ANOVA table for the model is shown in table 5.

Table 5: Analysis of Variance (ANOVA) table for the Regression Model for Co- Alignment between IT strategy - Performance Contract and IT strategy - Organizational Structure Alignment and Institutional

Performance

\begin{tabular}{lrrrrr}
\hline Model & $\begin{array}{l}\text { Sum of } \\
\text { Squares }\end{array}$ & $\begin{array}{l}\text { Degrees of } \\
\text { freedom }\end{array}$ & $\begin{array}{l}\text { Mean } \\
\text { Square }\end{array}$ & F & Significance \\
\hline Regression & 1.717 & 2 & 0.859 & 8.960 & 0.003 \\
Residual & 1.342 & 14 & 0.096 & & \\
\hline Total & $\mathbf{3 . 0 5 9}$ & $\mathbf{1 6}$ & & & \\
\hline
\end{tabular}

The results of the multiple regression showed that co-alignment of IT strategy-Performance Contract and IT strategy- IT organisational structure positively influences instituional performance. This supports similar findings [15] which returned the same results.

It also proves our hypothesis H3:Co-Alignment between IT strategy-Performance Contract and IT strategy-IT Organizational structure Alignment has a positive statistical significant effect on institutional performance to be true.

\section{DISCUSSION OF RESEARCH FINDINGS}

\subsection{Discussion of the Strategic IS Alignment Model}

The results of the data analysis suggest that the relationships in the strategic IS alignment model diagram are realistic. The findings in this study have shown that when IT strategy is aligned with Performance contract, institutional performance is improved which is in agreement a study [8] that that showed that the fit created through strategic alignment of the organizational and technological infrastructure enhances business performance and also another study [28] that asserted that the inability of a firm to realize value from IT investments is, in part, due to a lack of alignment between the business and IT strategies of organizations.

In addition, the findings showed that when IT strategy is aligned with IT organizational structure, institutional performance is enhanced. This agrees with a study [15] that asserted that a performance of a firm depends on the degree of coherence between its structure, which is considered as a foundation of a firm's strategic technological choice, and its environment. Similar findings [8] indicated that with effective IT organizational structure, IT departments can better transform their resources according to business needs without destroying IT strategic goals.

Finally, our findings indicated a positive effect on institutional performance when IT strategy is aligned with Performance contract and IT organizational structure. This is in agreement with previous research findings [15] that indicated that aligning IT strategy to the partnership strategy of the SME and to its organizational structure allows it to generate best performance levels.It also agrees with another previous research [9] which asserted that an "aligned" organization will be operating at peak effectiveness. 
International Journal of Managing Public Sector Information and Communication Technologies (IJMPICT) Vol. 8, No. 2, June 2017

\subsection{Influence of alignment of IT strategy and Performance Contract on institutional performance}

The study established that majority of the public universities perceive IT as an effective tool and enabler of processes in the institution. The findings further showed a positive correlation between alignment of IT strategy and Performance contract on institutional performance. According to the study, the overall mean response rating for alignment between IT strategy and performance contract (corporate strategy) achievement in the universities was found to be 4.15 out of 5 which translated to $83 \%$. This meant that, IT alignment with performance contract in public universities achieved the following for the institutions: Improved customer satisfaction; Reduction in total operational costs; Better return on IT investment; High Quality Product and Improved use of IT to support university operations and therefore improving on overall institutional performance.

\subsection{Influence of alignment of IT strategy and IT organizational structure on institutional performance}

The findings indicated that, in most public universities, the IT executives are involved in development of the corporate strategies i.e. the strategic plan and the performance contract targets. It further revealed that majority of the highest IT executive in public universities, report directly to the top management. A high commitment by top management in supporting strategic use of IT was seen in the study findings with top management effectively addressing management factors like recruitment, training and development, project funding and motivation of ICT staff in order to improve process efficiency and effectiveness. Majority of the respondents therefore perceived alignment of IT strategy with IT organizational structure as key in improve overall institutional performance.

\subsection{Recommendations}

Even though strategic alignment was found to influence institutional performance, a few public universities were not aligned. The study therefore recommends that the top management of all public universities should embrace strategic alignment through adoption of the conceptual framework developed in this study to improve on their institutional performance.

This study further recommends the Government of Kenya through the directorate of Performance Contracting to customize the annual Performance contract guidelines on automation to ensure that it reflects on the mission and vision of the university sector as opposed to providing general automation guidelines to all state agencies. The study also recommends to the Ministry of Education to increase budget allocation for ICT related activities in public universities to ensure that most of the ICT targets projected at the beginning of every financial year are achieved.

Finally, the study recommends introduction of performance contracts by the Government of Kenya to private universities to ensure that quality is improved and performance measurement is standardized.

\subsection{Suggested Areas for Further Research}

This study focused on Kenyan Public Universities only. The study recommends that similar studies be undertaken in private universities but using other corporate strategies like strategic plan or balance score card since private universities don't sign performance contracts with the Government. Further empirical work is encouraged to test the metrics of performance used in the 
conceptual model; improved quality and high returns on IT investment as opposed to relying on user perceptions.

\subsection{Contribution of Research}

Our research contributes to the literature on strategic IT alignment through: (i) the development of a model to test the underlying strategic alignment factors that influence organizational performance; (ii) the development of some theoretical viewpoints on strategic IT alignment; and (iii) enhancing understanding of the influence of the scarcely examined performance contracts on strategic IT alignment.

\section{CONCLUSIONS}

The findings in this study have shown that when IT strategy is aligned with Performance contract, institutional performance is improved; when IT strategy is aligned with IT organizational structure, institutional performance is enhanced; and, there is a positive effect on institutional performance when IT strategy is aligned with Performance contract and IT organizational structure. Some of the benefits realized through strategic alignment according to the study findings include introduction of ICT enabled teaching for lecturers, biometric systems for students and staff registration and access control, online application platforms like online hostel booking, online admission systems among others. IT infrastructure has also improved with most of the public universities investing in wireless networks for students, digital repository for library materials and ICT enabled research with statistical tools being introduced in the institutions for gathering and analyzing research data effectively.

\section{REFERENCES}

[1] Al-Hatmi, A. (2012). Analysis of ICT Strategic Alignment In a Public Organization.

[2] Avison, D., Jones, J., Powell, P., \& Wilson, D. (2004).Using and validating the strategic alignment model. The Journal of Strategic Information Systems, 13(3), 223-246.

[3] Broadbent, M., \& Weill, P. (1993). Improving business and information strategy alignment: Learning from the banking industry. IBM systems Journal, 32(1), 162-179.

[4] Chan, Y. E., \& Huff, S. L. (1993, December). Investigating information systems strategic alignment.In ICIS (pp. 345-363).

[5] Chan, Y. E., Sabherwal, R., \& Thatcher, J. B. (2006). Antecedents and outcomes of strategic IS alignment: an empirical investigation. IEEE Transactions on engineering management, 53(1), 2747.

[6] Chatzoglou, P. D., Diamantidis, A. D., Vraimaki, E., Vranakis, S. K., \&Kourtidis, D. A. (2011).Aligning IT, strategic orientation and organizational structure. Business Process Management Journal, 17(4), 663-687.

[7] Chebrolu, S. B., \& Ness, L. (2013). How Does Alignment of Business and IT Strategies Impact Aspects of IT Effectiveness?. International Journal of Applied Management and Technology, 12(1).

[8] Chou, F. K., Wang, E. T., \& Yang, F. W. (2015).Realizing IT Strategic Alignment and Business Performance: An Integration of Three Perspectives.

[9] Chorn, N. H. (1991). The "alignment" theory: Creating strategic fit. Management Decision, 29(1).

[10] Croteau, A. M., \& Bergeron, F. (2001). An information technology trilogy: business strategy, technological deployment and organizational performance. The journal of strategic information systems, 10(2), 77-99.

[11] Ettlie, J. E., Bridges, W. P., \&O'keefe, R. D. (1984). Organization strategy and structural differences for radical versus incremental innovation.Management science, 30(6), 682-695. 
International Journal of Managing Public Sector Information and Communication Technologies (IJMPICT) Vol. 8, No. 2, June 2017

[12] Henderson, J. C., \&Venkatraman, N. (1989). Strategic alignment: a framework for strategic information technology management.

[13] Henderson, J. C., \&Venkatraman, N. (1993). Strategic alignment: Leveraging information technology for transforming organizations. IBM systems journal, 32(1), 4-16.

[14] Hill, T. (2005) Operations management, Palgrave Macmillan, New York, NY.

[15] Jouirou, N., \&Kalika, M. (2004). Strategic alignment: a performance tool (an empirical study of SMEs). AMCIS 2004 Proceedings, 467.

[16] Kearns, G.S. and Lederer, A.L. (2004), "The impact of industry contextual factors on IT focus and the use of IT for competitive advantage”, Information \& Management, Vol. 41 No. 2, pp. 899-919.

[17] Kobia, M., \& Mohammed, N. (2006, December).The Kenyan experience with performance contracting.In 28th annual roundtable conference of the African Association for Public Administration and Management, December (pp. 4-8).

[18] Liljenström, S. (2011).Driving Strategic Value from IT: Aligning scorecards and Metrics to determine strategic effectiveness.

[19] Luftman, J. (1996). Competing in the Information Age: Practical applications of the strategic alignment model.

[20] Luftman, J., \& Brier, T. (1999). Achieving and sustaining business-IT alignment. California management review, 42(1), 109-122.

[21] Maes, R., Rijsenbrij, D., Truijens, O., \&Goedvolk, H. (2000). Redefining business: IT alignment through a unified framework.

[22] Orodho, J. A. (2005). Elements of education and social science research methods. Nairobi: Masola Publishers.

[23] Peterson, R. R. (2001). Configurations and coordination for global information technology governance: complex designs in a transnational European context. In System Sciences, 2001.Proceedings of the 34th Annual Hawaii International Conference on (pp. 10-pp).IEEE.

[24] Sabherwal, R., \&Kirs, P. (1994).The alignment between organizational critical success factors and information technology capability in academic institutions. Decision Sciences, 25(2), 301-330.

[25] Schniederjans, M., \& Cao, Q. (2009). Alignment of operations strategy, information strategic orientation, and performance: an empirical study.International Journal of Production Research, 47(10), 2535-2563.

[26] Smits, M., Fairchild, A., Ribbers, P., Milis, K., \&Geel, E. V. (2009).Assessing strategic alignment to improve IT effectiveness. BLED 2009 Proceedings, 15.

[27] Sohal, A.S. and Lionel, N.G. (1993), "The role and impact of information technology on Australian business", Journal of Information Technology, Vol. 13 No. 1, pp. 201-11.

[28] Tallon, P. P., \& Kraemer, K. L. (2003).Investigating the relationship between strategic alignment and IT business value: the discovery of a paradox.Creating Business Value with Information Technology: Challenges and Solutions. Hershey, PA: Idea Group Publishing, 1-22.

[29] Yayla, A. A., \& Hu, Q. (2012). The impact of IT-business strategic alignment on firm performance in a developing country setting: exploring moderating roles of environmental uncertainty and strategic orientation. European Journal of Information Systems, 21(4), 373-387.

\section{Authors}

Agnes Wausi is the Director, School of Computing and Informatics at University of Nairobi, Kenya. She holds Doctorate of Science Degree in Information Systems from University of Nairobi, Kenya and Masters of Science degree in computer science from Vrije Universitiet Brussels, Belgium.

Zachary Waweru is a Systems Administrator at the Commission for University Education, Kenya. He holds a Masters of Science degree in Information systems from University of Nairobi, Kenya and a Bachelor of Science Degree in information Technology from Jomo Kenyatta University of Science and Technology. Kenya.

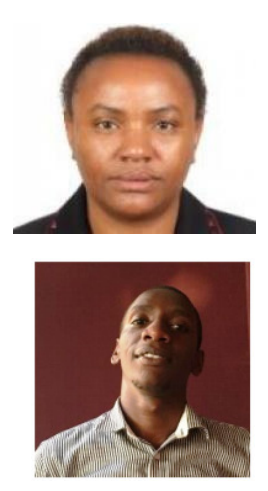

